\title{
Molecular Characterization of Some Egyptian cotton Varieties
}

\author{
Issraa Saif $^{1}$, Seehy, M.A ${ }^{1}$, Sanaa Riad ${ }^{2}$, Mahmoud Elbagoury ${ }^{2}$
}

\begin{abstract}
Cotton plant belongs to the genus Gossypium which is considered as the first important economic crop in Egypt. The present study aims to characterize five Egyptian cotton varieties $(\operatorname{Giza}(G) \quad 92 ; \operatorname{Giza}(G) \quad 93 ; \operatorname{Giza}(G) 86$; $\operatorname{Giza}(G) 87$ and $\operatorname{Giza}(G) 88)$ at biochemical and molecular level. Using ISSR; SSR and RAPD-PCR analyses, a total of 159 polymorphic fragments were recorded with similarity of $40 ; 23.5$ and $38 \%$, respectively, for the five varieties. The Phylogenetic relationships of the five Egyptian cotton varieties based on DNA molecular data (RAPD + ISSR + SSR) indicated two groups with $56 \%$ similarity; the first group had (G88); However, G93 and G86 with homology percentage of $81 \%$, and both of them in relation to $\mathbf{G 8 7}$ variety with approximately $65.5 \%$ similarity.
\end{abstract}

Keywords: Cotton, Molecular Markers, ISSR, SSR, RAPD-PCR

\section{INTRODUCTION}

Cotton is an important natural plant of the genus Gossypium and a shrub native to tropical and subtropical regions. It is fluffy staple fiber that grows in a boll or protective capsule around seeds and used to make a soft breakable textile. The fiber is almost pure cellulose and aid in seed dispersal, according to Basra and Malik (1984) as well as Ruan and Chourey (1997).

It is independently domesticated around the old and new worlds including Americas; Africa and India. Four commercially-grown species of cotton had been domesticated in antiquity. Gossypium hirsutum - upland cotton, native to Central America; Mexico; Caribbean and Southern Florida ( $90 \%$ of world production). Gossypium barbadense - known as extra-long staple cotton, native to tropical South America (8\% of world production). Gossypium arboreum - tree cotton, native to India and Pakistan (less than $2 \%$ of world production). Gossypium herbaceum - Levant cotton, native to Southern Africa and Arabian Peninsula (less than $2 \%$ of world production). (Edwards and Mirza 1979)

The Gossypium genus comprises about 45 diploid species with 26 chromosomes and 5 allotetraploid species (tetraploids derived following hybridization of two diploids) with 52 chromosomes (Brubaker et al.,1999a; Esmail et al.,2017). Based on chromosomal similarities, Gossypium species commonly are grouped into eight diploid genomic groups ( $\mathrm{A}-\mathrm{G}$ and $\mathrm{K}$ ) and one tetraploid genomic group (Edwards and Mirza,
1979 and Endrizzi et al., 1985 and Stewart, 1995). Two economically important cultivated tetraploid species of $G$. hirsutum (Upland cotton) and G. barbadense (Caribbean "Sea-Island"-"Extra Long Staple"; modern "Pima" and "Egyptian"cultivars) dominate world cotton production (Chen et al., 2007).

In the past decades, molecular markers such as biochemical constituents and macromolecules (proteins and DNA) have very rapidly complemented the classical strategies (Weising et al., 1995). Recently, the term DNA fingerprinting/profiling is used to describe the combined use of several single locus detection systems and are being used as versatile tools for investigating various aspects of plant genomes. These include characterization of genetic variability; genome fingerprinting; genome mapping; gene localization; analysis of genome evolution; population genetics; taxonomy; plant breeding and diagnostics (Joshi et al., 1999).

The present study aims to investigate and characterize five Egyptian cotton varieties. To achieve this purpose some physical properties (length; strength; fineness; uniformity....etc.) were measured using High Volume Instruments (HVI). In addition, the phylogenetic relationships of these varieties were designed according to some DNA molecular markers (ISSR; SSR and RAPD) as well as Peroxidase isozymes data.

\section{MATERIALS AND METHODS}

\section{MATERIALS}

Five different Egyptian cotton (Gossypium barbadense L.) genotypes were used in this study: G92,G93,G86, G87 and G88 and were obtained from Sakha station.

Fine chemicals for DNA isolation; polymerase chain reaction (PCR) primers kits and Peroxidase chemicals were used. The following three tables present the primers used for RAPD; ISSR and SSR analyses.

\section{METHODS}

\section{High volume instrument (HVI) testing:}

HVI 1000 (Uster, Switzerland) was used as standard test methods for measurement of fiber quality traits and the most important physical properties of cotton fiber, i.e. fiber length $(\mathrm{mm})$; fiber strength $(\mathrm{g}$ tex-1) and fiber fineness (micronaire).

\footnotetext{
${ }^{1}$ Department of Genetics, Faculty of Agriculture, Alexandria University.

${ }^{2}$ Cotton Arbitration and Testing General Organization (CATGO)

Received February 27, 2017, Accepted March 22, 2017
} 
Table 1.P rimers used for RAPD-PCR reactions

\begin{tabular}{lcc}
\hline Primer number & Primer code & Sequence (5`-3) \\
\hline 1 & OPA-02 & CAT CCC CCT G \\
2 & OPA-03 & TTC GAG CCA G \\
3 & OPA-04 & GTG AGG CGT C \\
4 & OPC-03 & GGG GGT CTT T \\
5 & OPC-12 & TGT CAT CCC C \\
\hline
\end{tabular}

Table 2. Primers used for ISSR- PCR reactions

\begin{tabular}{lcl}
\hline Primer number & Primer code & Sequence (5`-3) \\
\hline 1 & OPA-01 & CAG GCC CTT C \\
2 & OPA-02 & AGG GGT CTT G \\
3 & OPA-03 & CTG GGG ACT T \\
4 & OPA-04 & TTC CCC CGC T \\
5 & OPA-05 & GAT GAC CGC C \\
\hline
\end{tabular}

Table 3. Primers used for SSR-PCR reactions

\begin{tabular}{lrr}
\hline Primer & Sequence of forward primers & Sequence of reverse primers \\
\hline 166 wme & CCACCATGGTGCTAATAGTGTC & AGCTCGTAACGTAATGCAACTG \\
XTXP-8 & ACATCTACTACCCTCTCACC & ACACATCGAGACCAGTTG \\
XTXP-10 & ATACTATCAAGAGGGGAGC & AGTACTAGCCACACGTCAC \\
XTXP12 & ATATGGAAGGAAGAAGCCGG & AACACAACATGCACGCATG \\
XTXP-19 & ATACTATCAAGAGGGGAGC & AGTACTAGCCACACGTCAC \\
XTXP-20 & ATACTATGAACAGGGCAGC & AGTGCTAGCCACACGTGAC \\
\hline
\end{tabular}

\section{Test method for Micronaire reading:}

A predetermined mass of loose cotton was placed in the specimen holder and compressed to a fixed volume. The resistance to air flow, using constant pressure compressed air, was measured and the pressure drop across the plug of cotton was expressed as micronaire. The pressure drops associated with micronaire were determined by performing tests on a wide range of cottons, which were previously established as micronaire values.

\section{Test method for fiber length:}

Fibers were placed on a comb in such a way that they are caught at random along their lengths to form a beard. The beard was scanned from base to tip. In the Spinlab system, the amount of light passing through the beard was used as a measure of the number of fibers that extend various distances from the comb. In the Motion Control system, the pressure drop across an orifice was used to measure the number of fibers that extend various distances from the comb.

\section{Test method strength:}

For the Spinlab system, the measurement of cotton fiber strength and elongation was made by the same apparatus that measures fiber length and length uniformity. For the Motion Control system, the measurement of cotton fiber strength and elongation was made by the Strength Analyzer.

\section{Leaf tissue preparation:}

About $0.05-0.1 \mathrm{~g}$ young leaves $(2.0-2.5 \mathrm{~cm}$ in diameter) were harvested; folded and placed in a $1.5 \mathrm{~mL}$ microcentrifuge tube. Samples were kept on ice. Liquefied N2 was used to freeze tissues and then grinded to a fine powder in a $1.5 \mathrm{~mL}$ microcentrifuge tube with a pellet pestle.

\section{DNA extraction:}

CTAB methods. The quality and quantity of extracted DNA were controlled on a $0.6 \%$ agarose gel. Electrophoresis was performed in $1 \times \mathrm{TBE}$ running buffer, $\mathrm{pH} 8.0$, at $100 \mathrm{~V}$. The agarose gel was checked with a Spectrophotometer DV530 (Beckman, Germany). DNA was quantified by fluorometry and adjusted to 20 $\mathrm{ng} / \mu \mathrm{L}$ in distilled water.

Random Amplified Polymorphism DNA (RAPD) Inter-Simple Sequence Repeat (ISSR) - Simple Sequence Repeats (SSR):

The genomic DNA was amplified using the primers in table (1,2 and 3$)$. The amplifications reactions were carried out in final volume of $20 \mu \mathrm{l}$. Each reaction mixture contained $2 \mu$ l DNA template (concentration $30 \mathrm{ng} / \mu \mathrm{l}$ DNA); $2 \mu \mathrm{l}$ of $10 \times$ PCR buffer; $4.5 \mu \mathrm{l}$ of 0.2 mMdNTPs; $2 \mu \mathrm{l}$ of $50 \mathrm{mM} \mathrm{MgCl}_{2}$ and $1.5 \mu \mathrm{l}$ of $30 \mathrm{ng} / \mu \mathrm{l}$ of each forward and reverse primer. The amplification was done for initial denaturation step of $5 \mathrm{~min}$ at $94^{\circ} \mathrm{C}$ and 35 cycles. Each cycle was applied as denaturation 
for $30 \mathrm{~s}$ at $94^{\circ} \mathrm{C}$; annealing for $30 \mathrm{~s}$ at $55^{\circ} \mathrm{C}$ and extension for $1 \mathrm{~min}$ at $72^{\circ} \mathrm{C}$. Final extension was done for $10 \mathrm{~min}$ at $72^{\circ} \mathrm{C}$. The amplified samples (each about $10 \mu \mathrm{l})$ were separated electrophoretically using a denaturing 3\% agarose gel, and also polyacrylamide gel. The ethidium bromide $(0.5 \mathrm{mg} / \mathrm{mL})$ was used to stain the gel for about $30 \mathrm{~min}$. and 100bp DNA ladder $(5 \mu \mathrm{l})$ was used as DNA marker. The gel was photographed under ultraviolet light, and fragment length was determined graphically by comparison with the DNA ladder marker. Data was scored as 0 for dearth of band and 1 for presence of band

\section{RESULTS}

Using the High Volume Instrument "HVI100 M700 USTER". The five Egyptian varieties were measured, and their results were as shown in Table (4)

Different DNA molecular analyses (RAPD; ISSR and SSR) were applied to estimate the genetic diversity among the five Egyptian cotton varieties.

\section{Random Amplified Polymorphic DNA (RAPD) analysis:}

Figure (1): DNA fingerprinting of the five Egyptian cotton varieties using different random primers (OPA-
02; OPA-03; OPA-04; OPC-03 and OPC-12). M: DNA marker; 1: G92; 2: G93; 3: G86; 4: G87 and 5: G88.

By using the primers in table (1) the numbers of amplified and polymorphic fragments as well as percentages of polymorphism per primer for the five Egyptian cotton varieties are shown in table (5).

\section{Inter-Simple Sequence Repeats (ISSR):}

Figure (2): Banding patterns of the five Egyptian cotton varieties using different ISSR primers (OPA-01; OPA02; OPA-03; OPA-04 and OPA-05). M: DNA marker; 1: G92; 2: G93; 3: G86; 4: G87 and 5: G88.

By using the primers in Table (2) the numbers of amplified and polymorphic fragments as well as percentages of polymorphism per primer for the five Egyptian cotton varieties were as shown in Table (6)

By using the primers in Table (3) the numbers of amplified and polymorphic fragments as well as percentages of polymorphism per primer for the five Egyptian cotton varieties.

The Phylogenetic relationships of the five Egyptian cotton varieties based on DNA molecular data (RAPD + ISSR + SSR) are as shown in Figure (4).
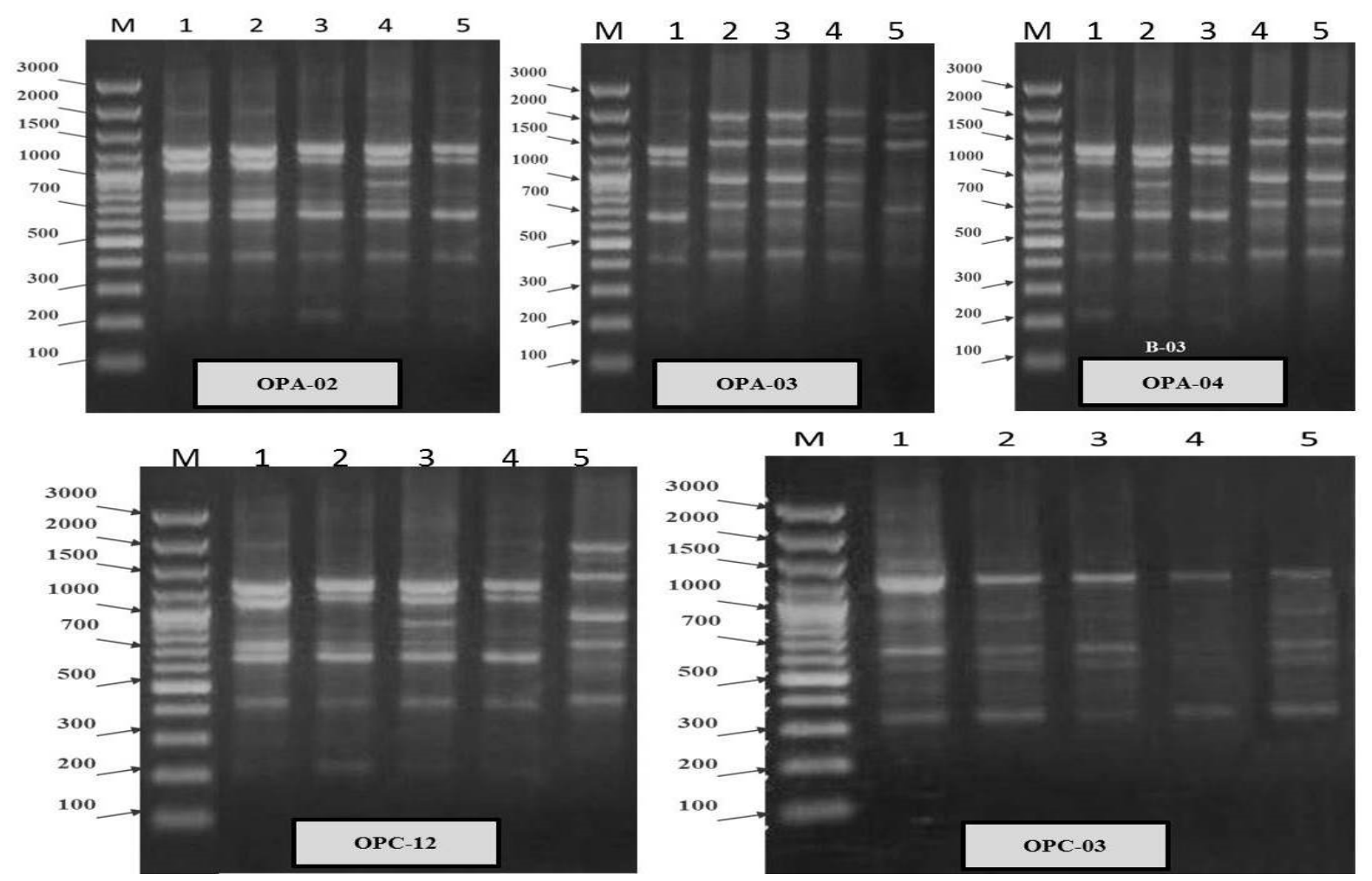

Figure 1. DNA fingerprinting of the five Egyptian cotton varieties using different random primers (OPA-02; OPA-03; OPA-04; OPC-03 and OPC-12). M: DNA marker; 1: G92; 2: G93; 3: G86; 4: G87 and 5: G88. 
Table 4. Measurements of some morphological and physical properties for the five Egyptian cotton varieties using HVI1000 M700 USTER

\begin{tabular}{cccc}
\hline Cotton variety & $\begin{array}{c}\text { Length } \\
(\mathbf{m m})\end{array}$ & $\begin{array}{c}\text { Fineness } \\
\text { Micronaire reading }\end{array}$ & $\begin{array}{c}\text { Strength } \\
(\mathbf{g m} / \text { tex })\end{array}$ \\
\hline \multirow{2}{*}{ G92 } & $32-34$ & $3.2-3.99$ & $42.0-49.7$ \\
& Long staple & Fine & Very strong \\
\hline \multirow{2}{*}{ G93 } & $34.0-36.6$ & $2.50-3.04$ & $39.0-44.9$ \\
& Extra-long staple & Extra fine & Very strong \\
\hline \multirow{2}{*}{ G86 } & $31.0-33.9$ & $3.8-4.99$ & $39.0-48.9$ \\
& Long staple & Fine & Very strong \\
\hline \multirow{2}{*}{ G87 } & $34.47-35.99$ & $3.00-3.32$ & $40.2-45.8$ \\
& Extra-long staple & Extra fine & Very strong \\
\hline \multirow{2}{*}{ G88 } & $30.00-35.89$ & $3.00-4.99$ & $35-44.9$ \\
& Extra-long staple & Extra fine & Very strong \\
\hline
\end{tabular}

Table 5. Number of amplified and polymorphic bands and the percentage of polymorphism based on RAPD

\begin{tabular}{lcccc}
\hline $\begin{array}{c}\text { Primer } \\
\text { code }\end{array}$ & $\begin{array}{c}\text { Number of } \\
\text { amplified bands }\end{array}$ & DNA length (bp) & $\begin{array}{c}\text { Number of } \\
\text { polymorphic bands }\end{array}$ & $\begin{array}{c}\text { Percentage of } \\
\text { polymorphism (\%) }\end{array}$ \\
\hline OPA-02 & 40 & $210-2500$ & 14 & 35 \\
OPA-03 & 45 & $200-2000$ & 20 & 44.4 \\
OPA-04 & 40 & $210-2000$ & 15 & 37.5 \\
OPC-03 & 25 & $210-2700$ & 8 & 32 \\
OPC-12 & 40 & $320-1500$ & 19 & 47.5 \\
Total & 190 & & 76 & 40 \\
\hline
\end{tabular}

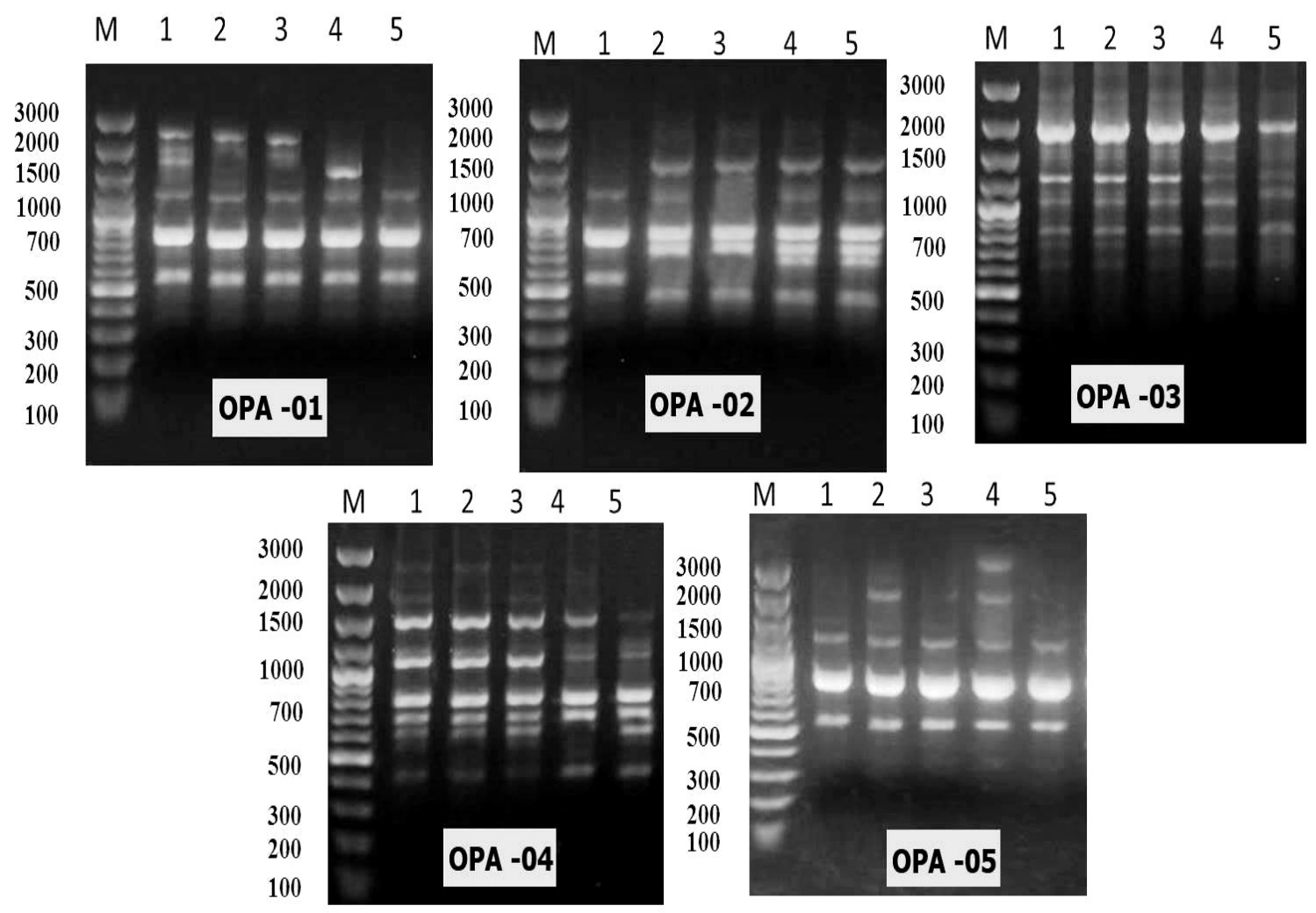

Figure 2: Banding patterns of the five Egyptian cotton varieties using different ISSR primers (OPA-01; OPA02; OPA-03; OPA-04 and OPA-05). M: DNA marker; 1: G92; 2: G93; 3: G86; 4: G87 and 5: G88. 
Table 6. Number of amplified and polymorphic fragments and the percentage of polymorphism per primer for the five Egyptian cotton varieties based on ISSR analysis

\begin{tabular}{ccccc}
\hline $\begin{array}{c}\text { Primer } \\
\text { code }\end{array}$ & $\begin{array}{c}\text { Number of } \\
\text { amplified bands }\end{array}$ & $\begin{array}{c}\text { DNA length } \\
\text { (bp) }\end{array}$ & $\begin{array}{c}\text { Number of } \\
\text { Polymorphic bands }\end{array}$ & $\begin{array}{c}\text { Percentage of polymorphism } \\
(\%)\end{array}$ \\
\hline OPA-01 & 25 & $350-2800$ & 5 & 20 \\
OPA-02 & 35 & $380-2500$ & 10 & 28.5 \\
OPA-03 & 25 & $550-2800$ & 4 & 16 \\
OPA-04 & 30 & $420-2800$ & 7 & 23.3 \\
OPA-05 & 25 & $350-3100$ & 7 & 28 \\
Total & 140 & & 33 & 23.5 \\
\hline
\end{tabular}

Simple Sequence Repeat (SSR) analysis:
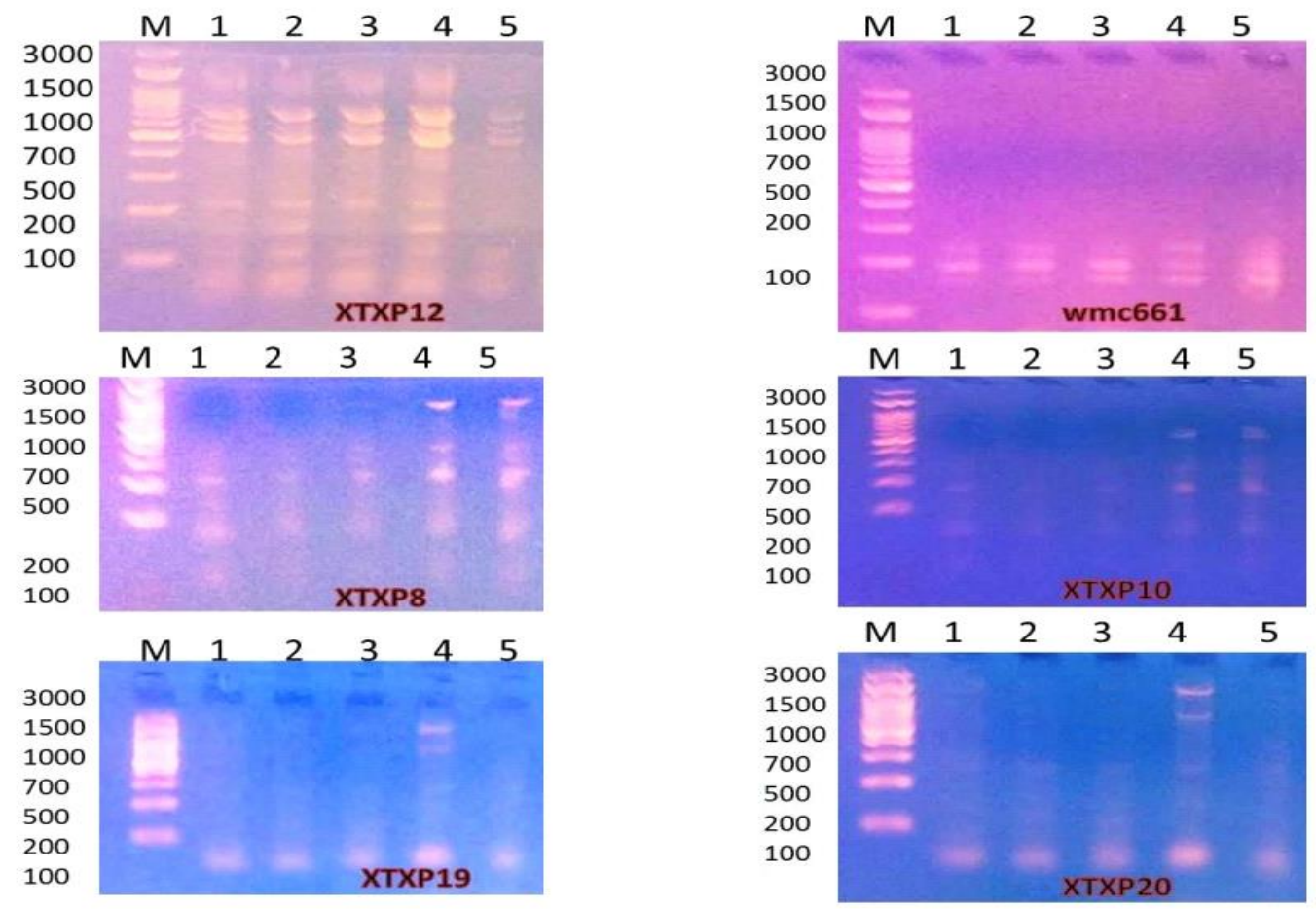

Figure 3. SSR banding profiles of the five Egyptian cotton varieties using six primers of specific sequence repeats (XTXP-12; wmc661; XTXP-8; XTXP-10; XTXP-19 and XTXP-20). M: DNA marker; 1: G92; 2: G93; 3: G86; 4: G87 and 5: G88.

Table 7. The number of amplified and polymorphic fragments and percentages of polymorphism per primer for five Egyptian cotton varieties based on SSR analysis.

\begin{tabular}{lcccc}
\hline Primer code & $\begin{array}{c}\text { Number of } \\
\text { amplified bands }\end{array}$ & $\begin{array}{c}\text { DNA length } \\
\text { (bp) }\end{array}$ & $\begin{array}{c}\text { Number of polymorphic } \\
\text { bands }\end{array}$ & $\begin{array}{c}\text { Percentage of } \\
\text { polymorphism (\%) }\end{array}$ \\
\hline XTXP12 & 35 & $50-2000$ & 10 & 28.5 \\
Wmc661 & 15 & $150-500$ & 3 & 20 \\
XTXP8 & 20 & $100-2000$ & 7 & 35 \\
XTXP10 & 20 & $200-1500$ & 7 & 35 \\
XTXP19 & 20 & $150-1500$ & 11 & 55 \\
XTXP20 & 20 & $60-2000$ & 12 & 60 \\
Total & 130 & & 50 & 38 \\
\hline
\end{tabular}




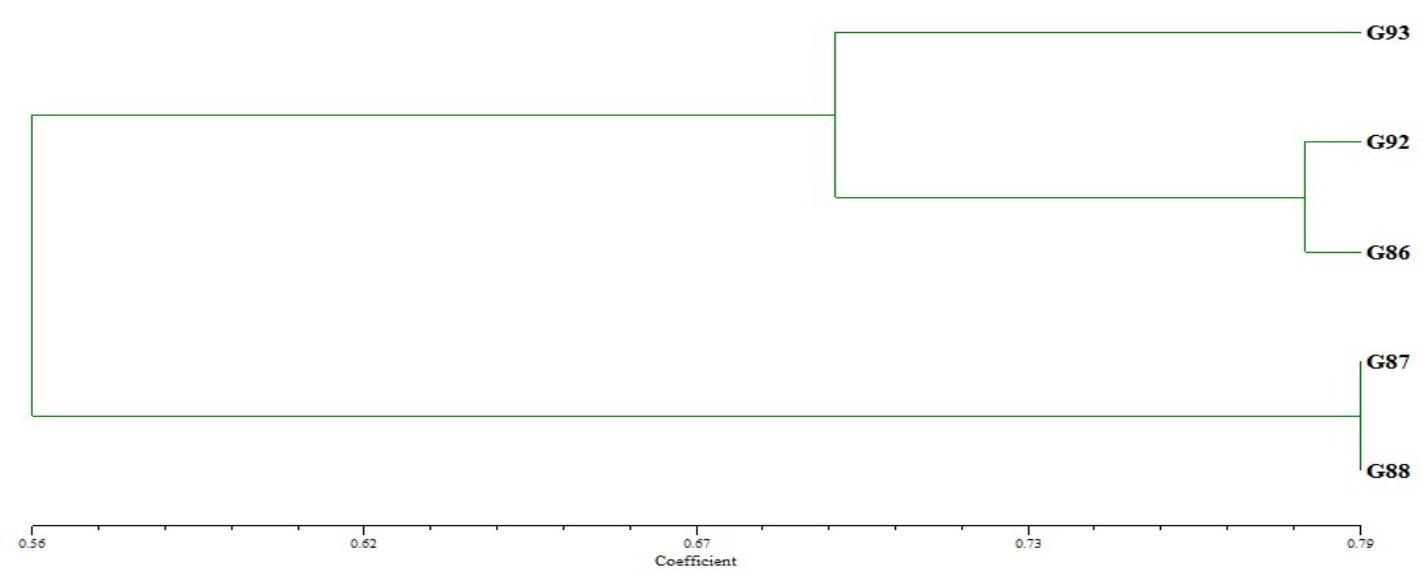

Figure 4.The polygenic relationship of the five Egyptian cotton varieties based on (RAPD+ISSR+SSR)

\section{DISCUSSION}

Since the Egyptian government is projected to elevate lint cotton production by increasing the total cultivated area and crop yield, which is associated with improving fiber quality and enhance biotic as well as abiotic tolerance (USDA, 2016). Therefore, it is very important to study the genetic diversity of Egyptian present cotton cultivars, which will be used in breeding programs for the development of new varieties and accessions (Abdel-Fattah, 2010). For this objective, attempts were made in the present investigation to characterize five Egyptian cotton varieties using some physical properties of cotton fibers as well as some DNA molecular markers.

The HVI instrument was mostly applied (Manandhar, 2013; ELÇ, et al., 2014; McCormick, 2015), and considered as main tool for cotton breeders to analyze fiber properties. According to Lacape et al. (2010), different physical characteristics of cotton fibers are measured ranging from fiber length and length uniformity such as strength; elongation; maturity; micronaire; fineness to color indices. Thus, in the present study, some of these physical properties (Length; micronaire and strength) were determined for the five different cotton fibers using HVI. Depending on the fiber length classification of the international cotton association-BREMEN, our Egyptian cotton cultivars were classified as long (G92; G86 and G88) and extralong (G93 and G87) staple cotton. Fiber length is largely determined by variety and affects yarn strength; yarn evenness; efficiency of spinning process and fineness (USDA, 2001). Our micronaire reading ranged from fine for the long staple cotton varieties (G92; G86 and G88) to extra-fine for the extra-long staple cotton cultivars (G93 and G87). These results are in agreement with the classification of cotton-USDA-feb2000, which reported that longer fiber is always finer fiber. In addition, strength measurements of the five Egyptian cotton varieties were determined as very strong fibers. Similar data was reported by EL Messiry et al. (2012) for G86; G87 and G88 varieties.

In this work, three PCR based markers (RAPD; ISSR and SSR) were applied to determine the genetic diversity and relationships among the five Egyptian cotton varieties. The highest number of the polymorphic fragments and percentage of polymorphism were reported for RAPD. In contrast, the least values were indicated for ISSR markers. SSR analysis revealed intermediate number of polymorphic amplicons and percentage of polymorphism. The overall finding from our data indicated that the three analyses sufficiently detected genetic diversity to differentiate the five Egyptian cotton varieties. The same conclusion was reported for different cotton genotypes after applying different DNA molecular markers (Jing et al., 2000; Hussein et al., 2002 \& 2006 \& 2007; El- Defrawy et al., 2004; Rana and Bhat, 2005; Esmail et al., 2008; Zahid et al., 2009). While, in the present study, RAPD analysis was more efficient than SSR and ISSR markers. In general, the variation in the number of amplicons by different primers influenced by variable factors such as primer structure; template quantity and number of annealing sites in the genome (Kernodle et al. 1993). Gossypium barbadense has limited genetic diversity. Abdellatif et al. (2012) indicated that the ancestors of all the Egyptian cotton cultivars bred in Egypt are limited to 4 varieties only (Ashmoni; Giza 12; Sakha 3 and Sakha 4) which confirms the narrow genetic background of the Egyptian cotton varieties. Therefore, RAPD analysis may offer a powerful tool for analyzing the genetic variability and relationships of cotton genotypes (El-Zanaty et al., 2011) because it mostly produce a 
large number of amplified fragments comparing with both SSR and ISSR markers (Kahodariya et al., 2015).

In the present study, UPGMA analyses were performed, and dendrograms were constructed. Based on RAPD; ISSR; SSR and combined data, two similar clusters with variable percentages of similarity were detected. The first cluster grouped G87 (G77 X G45A) as extra-long extra-fine variety with G88 (G77 X G45B) as long fine cultivar. This phylogenetic relationship may be related to their common ancestors, and also may explain why both varieties are related to each other despite their cotton fibers differences (Hussein et al., 2007). The second cluster included G93; G92 and G86 cultivars. For each DNA molecular data as well as all molecular data combined, the most related varieties were G92 and G86. This finding is in agreement with those obtained by Abdellatef et al. (2012). They analyzed 28 Egyptian cotton genotypes (varieties and hybrids) using different molecular markers (RAPD; SSR and EST). According to their cluster of all molecular data combined, they reported that G92 and G86 varieties are genetically closely related, and both of them in the same sub-cluster with Pima S6 as well as the same group with G93 variety (G77 X Pima S6). Although there is no clustering according to the pedigree history for G93 (G77 X Pima S6); G92 \{G84 X (G74 X G68)\} and G86 (G75 X G81) varieties and also in the cotton fiber properties as extra-long extra-fine (G93) and long fine (G92 and G86), DNA markers could better reveal the genotypic relationships when there are sufficient markers and they are distributed across all chromosomes (Zhang et al., 2005).

In conclusion, according to the high economic importance of the Egyptian cotton, considerable attention must be paid for improving cotton plants through breeding programs. The correlation between cotton fiber properties and DNA molecular markers (as rapid and accurate methods) facilitate the classification and the identification of cotton genotypes. In another aspect of the present study, using several DNA molecular marker types of different nature provides a better overall view of differentiation for cotton genotypes as well as evaluation of their genetic polymorphism and relationships. This could be a useful guide for selecting specific germplasm with distinct genetic backgrounds in cotton breeding programs for developing superior cultivars. Finally, further studies are needed to identify a connection among the phenotype and the genotype of the variety-specific markers that were detected in the current investigation.

\section{REFERENCES}

Abdel-fattah B. E.2010. Genetic characterization and relationships among Egyptian cotton varieties as revealed by biochemical and molecular markers. Egypt. J. Genet. Cytol., 39: 157-178.

Abdellatif, K.F., Y. A. Khidr, Y. M. El-Mansy, M. M.ElLawendey and Y. A. Soliman. 2012. Molecular Diversity of Egyptian Cotton (Gossypium barbadense L.) and its Relation to Varietal Development. Crop Sci. Biotech. 15 (2): $93-99$.

Basra A.S., C.P. Malik. 1984. Development of the cotton fiber. International Review of Cytology 87, 65-113.

Brubaker, C. L., A. H. D.Brown, Stewart J. McD., M.J. Kilby and J.P. Grace.1999. Production of fertile hybrid germplasm with diploid Australian Gossypium species for cotton improvement. Euphytica 108, 119-214.

Edwards, GA. and Mirza MA. 1979. Genomes of the Australian wild species of cotton. Il. The designation of a new G-genome for Gossypium bickii. Genet Cytol 21: 367-372.

El-Defrawy, M. M., M. M. Hashad and E. N. Elsayed .2004. Molecular polymorphism in egyptian cotton (Gossypium barbadense L.). Journal of Agricultural Science, 35: 8396.

ELÇI, E., A,Yaşar and A. Batuhan . 2014. Genetic diversity of Turkish commercial cotton varieties revealed by molecular markers and fiber quality traits. Turk J Bot, 38: 1274-1286

El Messiry, M. and S.A. M. Abd-Ellatif. 2012. Characterization of Egyptian cotton fibres. Indian journal of fiber and textile research. Vol. 38. pp.109-113.

Esmail1 S.A, S.Sh.EL-Tabbakh, A.I. Nawar and M.I. ELBagoury. The Effect of Blends between Some Egyptian cotton Varieties and Introduced Cottons on Technological and Spinning Characters. Alex.Sci.Exch.J.38(1):13-18.

El-Zanaty, A.M., Salem KFM. and Esmail R.M. 2011. Detection of genetic diversity in Egyptian cotton (Gossypium barbadense L.) varieties using RAPD markers and morphological traits. J. Am. Sci. 7: 1107-1015

Esmail, R. M., J. F. Zhang and A. M. Abdel-Hamid .2008. Genetic Diversity in Elite Cotton Germplasm Lines Using Field Performance and Rapd Markers. World Journal of Agricultural Sciences, 4: 369-375.

Hussein, E. A., M. Sh. Al-Said, H. A. El-Itriby and M. A. Madkour .2002. Genotyping Egyptian Cotton Varieties (G. barbadense) using molecular markers. (Poster) Biotechnology and Sustainable Development Voices of the South and North Conf. Held at the Bibliotheca Alexandrina Conference Center, March 16-20, Alexandria, Egypt.

Hussein, E.A., A. Mohamed, S. Attia and S. S. Adawy .2006. Molecular characterization and genetic relationships among cotton genotypes 1-RAPD, ISSR and SSR analysis. Arab J. Biotech., 9: 313-328. 
Hussein, E.H.A., M.H.A.Osman, M.H .Hussein and S.S.Adawy .2007. Molecular Characterization of Cotton Genotypes Using PCR-based Markers. J Appl Sci Res 10: 1156-1169.

Jing, K. Z., S. Ji-Zhong, Z. Jin-Fa, N. Yi-Chun and L. Jin-Lan .2000. Genetic diversity evaluation of some Chinese elite cotton varieties with RAPD markers. Acta Genetica Sinica, 27: 817-823.

Joshi, S.P., V.S .Gupta, R.K .Aggarwal, P.K .Ranjekar and D. S. Brar .1999. Genetic diversity and phylogenetic relationship as revealed by inter simple sequence repeat (ISSR) polymorphism in the genus Oryza .Theoretical and Applied Genetics ,100, pp.1311-1320.

Kahodariya, J., S. Pritesh and D. Vakharia. 2015. Assessment of genetic diversity in old world and new world cotton cultivars using RAPD and ISSR markers. Indian Journal of Biotechnology.vol.14. pp 511-517.

Kernodle, S. P., R. E. Cannon and J. G. Scandalios .1993. Rapid and simple phage DNA isolation. Biotechniques, 14:360:362.

Lacape, J.M., J. Jacobs, T. Arioli, R. Dericker, N. ForestierChiron, D. Llewellyn, J. Jean, E. Thomas and C. Viot. 2010. A new interspecific, Gossypium hirsutum x $G$. barbadense, RIL population: towards a unified consensus linkage map of tetraploid cotton. Theor. and Appl. Genetics 119:281-292.

Manandhar, R. 2013. Impact of cotton fiber maturity for cotton processing. Texas Tech University.
McCormick, D.S., V.J. Colclasure, T.J. Soderquist, T.Lynch, N.Schubert, E.Urrutia, C.Knickerbocker, D. McCord and J.H. Kavouras . 2015.Coliform bacteria, fabrics, and the environment. 43(2):154-8.

Rana,M.K. and K.V. Bhat .2005. RAPD markers for genetic diversity study among Indian cotton cultivars. Current Sci 88: 1956-1961.

Ruan,Y.L., P.S.Chourey ,D.P. Delmer, L.Perez-Grau . 1997.The differential expression of sucrose synthase in relation to diverse patterns of carbon partitioning in developing cotton seed. Plant Physiol. 115:375-385.

Stewart, J. McD. 1995. Potential for crop improvement with exotic germplasm and genetic engineering. In G. A. Constable and N. W. Forrester (eds.). Challenging the Future: Proceedings of the World Colton Research Conference-f. CSIRO, Melbourne, Australia, pp. 313-327.

United States Department of Agriculture. 2001.Crop production.

United States Department of Agriculture. 2016.Crop production.

Weising, K., H.Nybom and K. K. G.Wolff .1995.DNA fingerprinting in plants: principles, methods, and applications, 2nd edn. CRC Press, Boca Raton, FL.

Zahid, M., F. Raheel, A. S. Dasti, S. Shahzadi, M. Athar and M. Qayyum.2009. Genetic diversity analysis of the species of Gossypium by using RAPD markers. African Journal of Biotechnology, 8: 3691-3697.

Zhang, X.L., Y.C.Nie, X.P.Guo, C.D.Feng, J.M.Stewart, Z.X.Lin and D.H.He. 2005.Linkage map construction and mapping QTLs for cotton fiber quality using SRAP, SSR and RAPD. Plant Breed. 124: 180-187.

\section{الملخص العربي

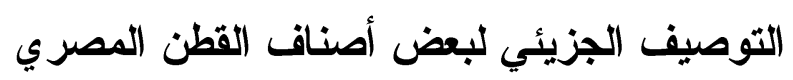 \\ إسر اء سيف، محمد الصيحي، سناء رياض، محمود الباجوري}

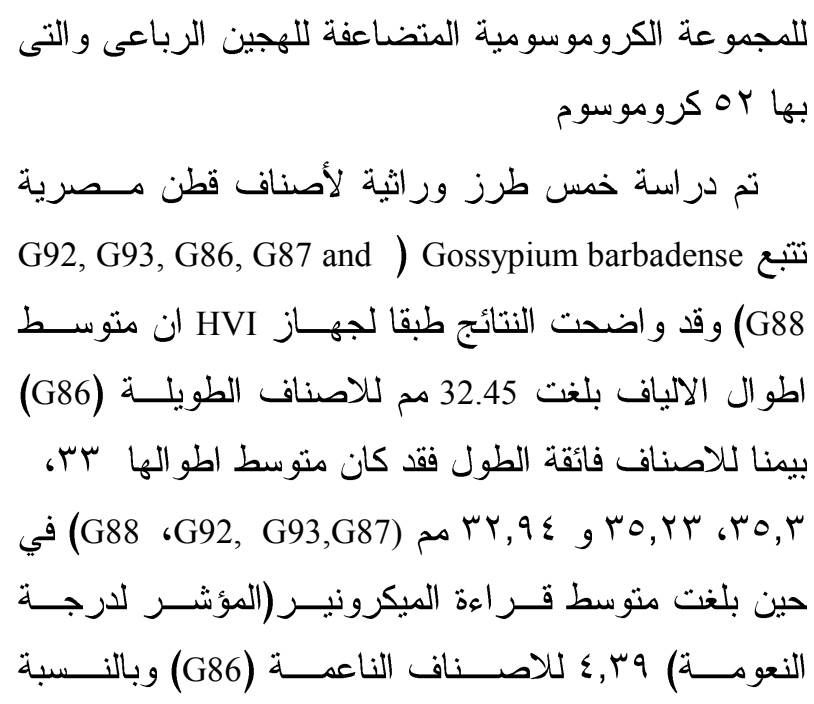


القطن الى جانب در اسةعمليات نقل الجين التى تفيد المربي

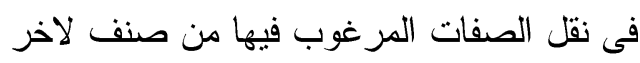
RAPD, طبقا لنتائج الو اسمات الجزيئيــة لتكنيكــات ال

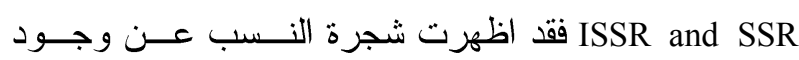
مجمو عتين متـشـابهتين بنـسب متغيـرة، حبــث تحتـوى المجموعة الاولي الاصناف فائقة الطول G87(G77XG45A) و G88(G77XG45B ونرجع هذه العلاقة الى وجود ابــاء مشتركين بينهم مما يوضح ارتباط هذين الصنفين ببعضهما

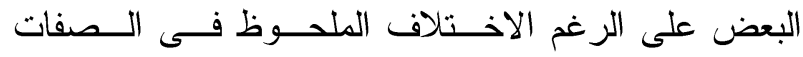
المظهرية للالياف لكل منهما. بينما تحتوى المجموعة الثانية على الاصناف G92(Giza84 x (Giza74, G93 (Giza77 X Pima S6)

.( x Giza 68), G86(Giza 75 x Giza 81)) ويستتنج من هذه الدراسة ان لابد مــن اهتـــام الدولـــة بتحسين القطن المصري كونه محصول اقتصادى هام وذللك من خلال بر امج التربية. حيث الارنباط مابين خو اص الياف

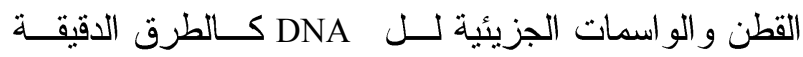
و السريعة يساعد في تصنيف وتعريــــ الطـــرز الور اثيـــة للقطن. وعلى صعيدا اخر استخدام العديد مـن الواســمات الجزيئية لل DNA من مصادر مختلفة يمنح در اسة عامــة

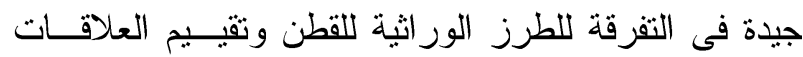

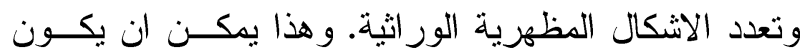
مرشدا جيد لعمليات انتخاب محتوي ور اثى محدد باصــول

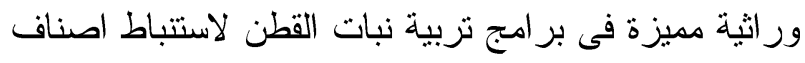

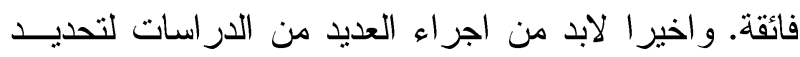

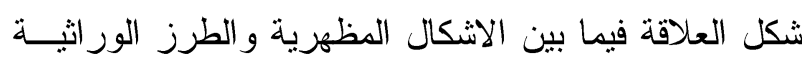

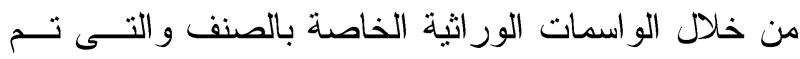
تحديدها فى هذه الدراسة.
للاصناف فائقة النعومة بلغت متوسط قر ائتها 09, Y، Y,VY،

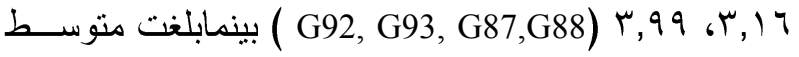
45.85, 41.95, 43.95, 43.00 المتانة للاصناف تحت الدر اسة (G92, G93, G86, G87 and G88) جم/ تكـس and 39.99

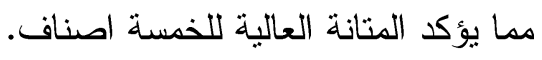
و على صعيد التحليل الجزيئي للخمـسة اصــناف تـم استخلاص ال DNA و إجراء ال PCR تفاعل السلسلة عديد البوليمر، حيث نم أستخدام خمس بادئات عشو ائية فى حالة

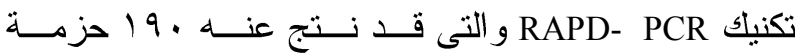

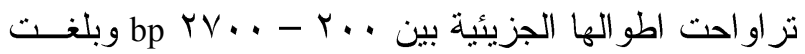

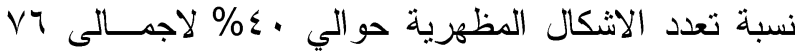

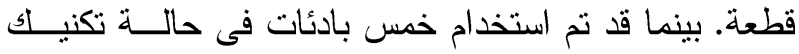
ISSR

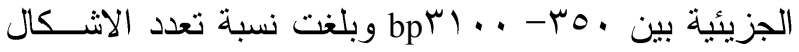

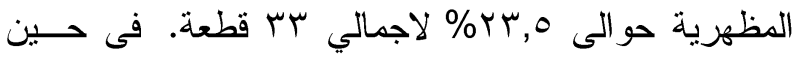

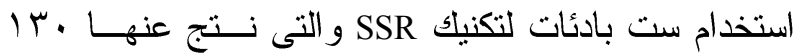

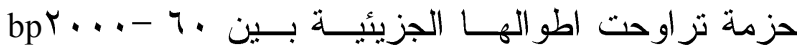

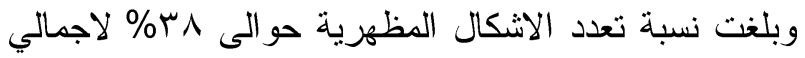
• من خلال استخدام ثــلاث تكنيكـات الواســـات الجزيئيــة RAPD, ISSR and SSR

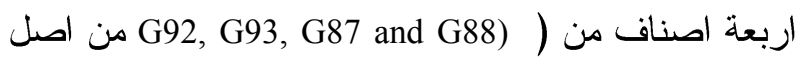

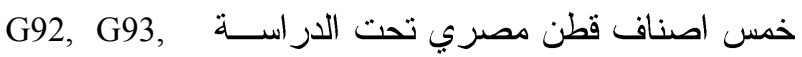
IV وذللك من خلال الكـشف عـن (G86, G87 and G88)

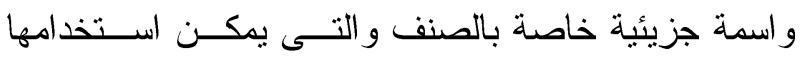

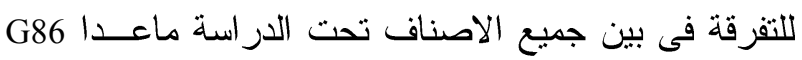
وبناءا على هذا جاء العديد مـنـ التقـاريرحول اســتخدام

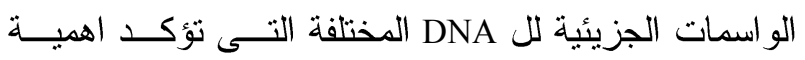

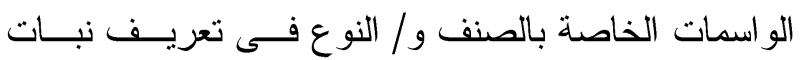

